ТРУБЧАНІНОВА К. А., канд. техн. наук, КОВТУН І. В., канд. техн. наук, РУБЛЬОВ В. О., магістрант, СОБОЛСВСЬКА Н. В., магістрант (Український державний університет залізничного транспорту)

\title{
Дослідження значення величини середньої затримки пакета даних інформаційних потоків у мережах передачі даних
}

Досліджується значення величини середньої затримки пакета даних інформаційних потоків у мережах передачі даних, для зменшення якої можливе використання змішаного методу маршрутизаиії, що забезпечує адаптацію до змін структури мережі передачі даних та мінімізацію впливу величини поточного трафіку на зміну стану каналів передачі даних за рахунок обліку максимальних значень інтенсивностей потоків даних при проведенні їх розподілу, що дозволяє істотно знизити службові потоки даних.

Ключові слова: середня затримка пакета даних, мережа передачі даних, статичні методи мармрутизації, динамічні методи мармрутизації, адаптивна марирутизація.

\begin{abstract}
Вступ
Сучасні досягнення у галузі телекомунікаційних та обчислювальних систем стали причиною розширення інформаційної взаємодії між окремими елементами системи. Це призвело до різкого збільшення обсягу інформації, що циркулює у обчислювальних системах та каналах передачі даних (ПД). Тому актуальним стає питання оптимізації структури мережі на основі використання алгоритмів маршрутизації. Нові методи маршрутизації повинні забезпечувати адаптацію процесу маршрутизації інформаційних потоків до змінення структури мережі передачі даних (МПД) та характеристик каналів передачі даних, що використовуються. Однією 3 найбільш важливих характеристик системи передачі даних (СПД), величина якої якраз i впливає на вибір методів маршрутизації інформаційних потоків, є середня затримка [1 - 3].
\end{abstract}

\footnotetext{
Аналіз останніх досліджень і публікацій

Головною методологічною основою для аналізу затримки пакета в СПД $\epsilon$ теорія масового обслуговування. Проте іiі використання часто вимагає спрощення припущень, тому що, на жаль, більш реалістичні припущення роблять змістовний аналіз затримки пакета надзвичайно складним. 3 цієї причини у деяких випадках неможливо провести точні кількісні розрахунки середньої затримки пакета даних у СПД на основі моделей теорії масового обслуговування. Тим не менше, ці моделі часто є основою для «розумних» апроксимацій середньої затримки пакета в мережі, а також дозволяють отримати корисні якісні результати.
}

В МПД для основних використовуваних методів маршрутизації можна зробити такі висновки:

- статичні методи маршрутизації, орієнтовані на незмінність маршрутів передачі даних, забезпечують низьку середню затримку пакетів даних у МПД при невисокому завантаженні каналів ПД, однак подальше збільшення завантаження каналів ПД призводить до виникнення частих блокувань у МПД і різкого збільшення середньої затримки пакетів даних в ній;

- динамічні методи маршрутизації дозволяють забезпечити меншу середню затримку пакетів даних у МПД в порівнянні зі статичними методами при високих значеннях завантаження каналів ПД за рахунок обліку поточного значення завантаження в ході маршрутизації інформаційних потоків, проте вони складні й вимогливі до ресурсів використовуваних обчислювальних засобів;

- для зменшення середньої затримки пакета даних у МПД можливе використання змішаного методу маршрутизації, що забезпечує адаптацію до змін структури МПД та мінімізацію впливу величини поточного трафіку на зміну стану каналів ПД за рахунок обліку максимальних значень інтенсивностей потоків даних при проведенні їх розподілу, що дозволяє істотно знизити службові потоки даних $[4,5]$. 


\section{Визначення мети та задачі дослідження}

У зв'язку 3 вищезазначеним метою роботи $\epsilon$ дослідження методу маршрутизації інформаційних потоків у мережах передачі даних, який забезпечує адаптацію процесу маршрутизації інформаційних потоків до змінення структури мережі передачі даних та характеристик використовуваних каналів передачі даних.

Об’скт дослідження - процес визначення оптимального маршруту у мережі за заданим критерієм.

Предмет дослідження - алгоритми статичної та динамічної маршрутизації інформаційних потоків.

Методи дослідження - теорія графів, теорія ймовірностей, математична статистика.

Задачі дослідження:

1. Дослідження величини середньої затримки пакета даних на маршруті.

2. Дослідження методів мінімізації середньої затримки пакета даних у мережі.

3. Дослідження методів розрахунку значень інтенсивностей потоків даних між окремими вузлами мережі.

4. Дослідження методів визначення раціональної довжини пакета даних.

\section{Основна частина дослідження \\ Двома головними завданнями, які вирішують методи маршрутизації інформаційних потоків, $є$ вибір маршрутів передачі даних для різних пар вузлів мережі i розподіл потоків інформації 3 них, а також забезпечення правильної доставки повідомлень їх адресатам після того, як були обрані маршрути. Вирішення другого завдання забезпечується шляхом використання різних мережевих протоколів. Наша основна увага буде приділена першому завданню (вибору маршрутів і розподілу потоків інформації по них) і тому, як це впливає на характеристики мережі ПД.}

Нехай є деяка послідовність операцій (керований захід), що дозволяє здійснювати вибір маршрутів і розподіл інформаційних потоків по них, на результат якого можливий вплив. Ефективність операції розподілу інформаційних потоків за маршрутами характеризується якимось критерієм або показником $P$, який потрібно звернути в максимум або мінімум. Всі чинники, від яких залежить результат виконання розподілу інформаційних потоків за маршрутами, діляться на дві групи:

- заздалегідь відомі, задані фактори, на які впливати неможливо (об'єктивні фактори);

- фактори, що залежать від виконання розподілу інформаційних потоків за маршрутами (елементи рішення).
У МПД необхідно вказати групу об'єктивних факторів, елементи рішення і визначити показник ефективності, на основі якого буде проводитися оптимізація.

До об'єктивних чинників, не залежних від розподілу інформаційних потоків за маршрутами, можна віднести такі характеристики мережі передачі даних:

- структуру МПД $S$;

- надійність МПД $G$.

Структура МПД визначається при іiї проектуванні і може видозмінюватися лише в процесі модернізації. Надійність МПД має лінійну функціональну залежність від структури самої мережі.

Приклад формалізованого представлення структури мережі у вигляді лінійного графа $S(Y, W)$ де $\boldsymbol{Y}$ - безліч вузлів, а $W$ - множина дуг (гілок), подано на рис. 1.

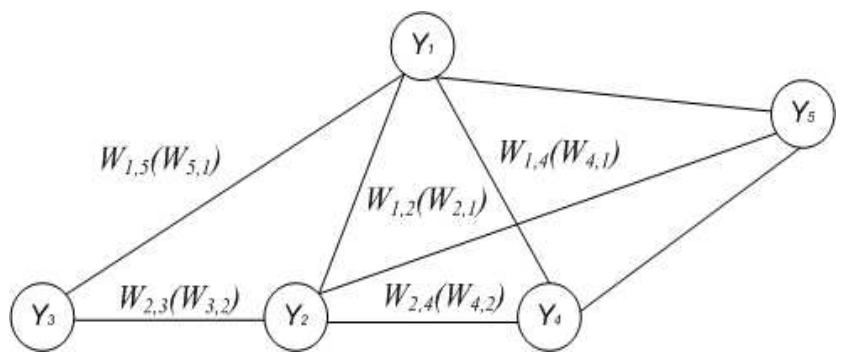

Рис. 1. Неорієнтований лінійний граф $S$, що відображає взаємозв'язок вузлів мережі

Лінійний граф може бути неорієнтованим, орієнтованим або частково орієнтованим. Сукупність ліній зв'язку, що не містять проміжних вузлів, входи яких знаходяться на вузлі $Y_{i}$, а виходи на вузлі $Y_{j}$, утворюють гілку $W_{i j}$. Кожна гілка характеризується довжиною $l_{w_{i j}}$, ємністю $p_{w_{i j}}$ і надійністю $g_{w_{i j}}$ Довжина гілки $l_{w_{i j}}$ визначається відстанню між вузлами $Y_{i}$ i $Y_{j}$ або іншим параметром гілки (вартість, величина загасання і т.д.). Смність гілки $p_{i w_{i j}}$ оцінюється такими параметрами, як максимальна швидкість передачі інформації, максимальна інтенсивність потоку даних з вузла $Y_{j}$ у вузол $Y_{j}$ або число стандартних каналів зв'язку. Надійність гілки $g_{w_{i j j}}$ залежить від імовірності справної дії лінії зв'язку даної гілки. Застосування тієї чи іншої оцінки довжини і ємності гілки залежить від конкретної розв'язуваної задачі. 
Кожен $Y_{j}$ - й вузол характеризується ємністю $p_{Y_{j}}$, обумовленою комутаційними можливостями обладнання вузла і надійністю $g_{Y_{j}}$, обумовленою ймовірністю справної дії обладнання даного вузла мережі.

Таким чином, основні характеристики мережі передачі даних, що містить $h_{Y}$ вузлів, можна подати у вигляді таких матриць: матриця зв'язності $W$, матриця ємностей гілок $p_{W}$, матриця довжин гілок $L_{W}$, матриця надійності гілок $G_{W}$.

До елементів рішення можна віднести характеристики МПД, що змінюються в процесі розподілу потоків даних за маршрутами: пропускна здатність мережі $p_{\text {слд, }}$, середня затримка пакета даних у мережі $T_{p}$, ефективність використання каналів ПД $\varepsilon_{w}$, економічність мережі $E_{c / z}$.

Всі перераховані характеристики в тій чи іншій мірі залежні від раціонального розподілу інформаційних потоків за маршрутами в мережі передачі даних.

У загальному випадку показник ефективності розподілу інформаційних потоків за маршрутами можна подати у вигляді

$F=F\left(p_{C \Pi M}, T_{p}, \varepsilon_{w}, E_{C \Pi M}\right)$

Існують різні думки про те, який показник $F$ (або група показників) $€$ визначальними i вимагають оптимізації. 3 іншого боку, безперечні труднощі аналітичного та обчислювального характеру стоять на шляху відшукання екстремального значення функціоналу (1). Тому доцільний розгляд окремих рішень задачі раціонального вибору маршрутів i розподілу потоків даних по них, спрямованих на оптимізацію певного показника.

Існують дві основні характеристики, на які істотно впливають методи маршрутизації інформаційних потоків - пропускна здатність мережі та середня затримка пакета даних в ній.

Маршрутизація інформаційних потоків (вибір маршрутів передачі даних) взаємодіє з управлінням потоками (розподілом потоків інформації) у визначенні характеристик мережі передачі даних за допомогою механізму зворотного зв'язку, показаного на рисунку 2.

У випадку, коли трафік від зовнішніх джерел, що надходить у корпоративну мережу передачі даних, малий, він повністю буде прийнятий мережею передачі даних i пропускна здатність мережі дорівнює навантаженню, що входить до неї.

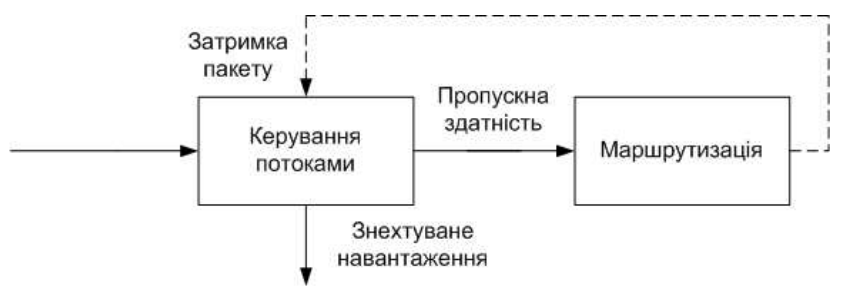

Рис. 2. Взаємозв'язок маршрутизації з керуванням потоками

При надмірно великому навантаженні, що входить до мережі передачі даних, частина цього навантаження буде відхилятися алгоритмом управління потоками, і в цьому випадку пропускна здатність мережі дорівнює різниці вхідного та відкинутого навантаження. Трафік, прийнятий в мережу, буде мати середню затримку пакетів, що залежить від того, які маршрути були вибрані методом маршрутизації. Якщо навантаження, що входить, велике, то раціональний вибір маршрутів збільшує пропускну здатність мережі при тому ж значенні середньої затримки пакета, а якщо навантаження, що входить, мале, то воно зменшує середню затримку пакета в ній. Крім того, необхідно, щоб метод маршрутизації забезпечував мінімізацію затримки пакета в мережі для будь-якого рівня iї пропускної здатності. Це дозволяє чітко сформулювати завдання розподілу інформаційних потоків по маршрутах 3 метою мінімізації середньої затримки пакета в мережі [3].

Виходячи з аналізу виразу [6], з якого випливає, що визначальними параметрами, які впливають на величину середньої затримки пакета даних в корпоративній мережі передачі даних, $є$ довжина маршрутів i інтенсивність потоків даних, що передаються ними, як показник ефективності задачі розподілу інформаційних потоків за маршрутами виберемо цільову функцію, яка визначається виразом

$$
F=\frac{1}{c_{u}} \cdot \sum_{j=1}^{h_{r}} \sum_{a=1}^{h_{m}} c_{m_{a}}^{j} \cdot l_{m_{a}}^{j}
$$

Величина $l_{m_{a}}^{j}$ визначається виразом

$l_{m_{a}}^{j}=\sum_{j=1}^{h_{w_{a}}^{j}} l_{w_{b}}$

де $l_{w_{b}}$ - довжина каналу передачі даних $w_{b}$, що входить до складу маршруту $m_{a}^{j} \cdot 3$ виразу 
випливає, що обрана цільова функція задачі розподілу інформаційних потоків за маршрутами в мережі визначається сумарним додатком значень довжин маршрутів і інтенсивностей потоків даних, переданих по них з урахуванням величини сумарної інтенсивності вхідного потоку в МПД.

Сформулюємо задачу раціонального розподілу потоків даних за маршрутами в МПД. Для кожної пари різних вузлів $x$ і $y$ МПД вхідний процес пакетів, що надходять, передбачається стаціонарним i має інтенсивність $u_{r_{j}}$. Таким чином, $u_{r_{j}}-$ це інтенсивність вхідного потоку (вимірювана в одиницях біт в секунду), що надходить в МПД у вузлі $x$ i адресований вузлу $y$. Мета розподілу потоків даних по маршрутах полягає в тому, щоб потік інтенсивністю $u_{r_{j}}$ розділити між кількома маршрутами від відправника до адресата так, щоб загальний потік за маршрутами в мережі, що виходить в результаті, мінімізував цільову функцію, яка визначається виразом (4).

Щоб дати більш точне формулювання задачі раціонального розподілу потоків даних, введемо такі позначення:

- $\boldsymbol{R}$ - безліч пар вузлів мережі, між якими проводиться обмін інформацією;

- $M^{j}-$ множина всіх маршрутів, що з'єднують $j$-ту пару вузлів мережі;

$-c_{m_{a}}^{j}-$ значення інтенсивності (одиниці біт в секунду) $j$-го потоку за маршрутом $m_{a}^{j}$.

Тоді набір всіх потоків за маршрутами $\left(m_{a}^{j} \mid r_{j} \in R \wedge a \in M^{i}\right)$ повинен задовольняти обмеження

$\sum_{a \in M^{j}} m_{a}^{j}=u_{r_{j}}$ для всіх $r_{j} \in R$;

$m_{a}^{j} \geq 0$ для всіх $a \in M^{j}, r_{j} \in R$.

Таким чином, завдання розподілу інформаційних потоків по маршрутах з метою мінімізації середньої затримки пакета даних у МПД може бути сформульовано як завдання знаходження потоків за маршрутами, які мінімізують цільову функцію (4) при вищевказаних обмеженнях. Це і є основним завданням адаптивної маршрутизації, яка буде розглянута нижче.

Розрахунок мінімальних значень інтенсивностей потоків даних між окремими вузлами мережі. Для виконання розподілу інформаційних потоків у МПД необхідно зробити попередній розрахунок значень інтенсивностей потоків даних, що циркулюють у ній. Спосіб розрахунку максимальних значень інтенсивностей потоків даних між окремими вузлами мережі $є$ складовою частиною методу адаптивної маршрутизації.

Дані на передачу від вузлів мережі надходять у випадкові моменти часу $t$. Тривалість передачі кожного окремого пакета даних також $є$ величиною випадковою. Сукупність вузлів мережі породжує стохастичний потік даних інтенсивністю $\boldsymbol{u}$, обслуговування якого реалізують вузли комутації (ЦКП) МПД. Мережа передачі даних, що містить сукупність ЦКП, являє собою складну багатофазну систему масового обслуговування (CMO), бо один і той же пакет даних обслуговується рядом ЦКП. Дослідимо поведінку однофазної СМО, що характеризує роботу окремого вузла мережі. Умовимося розглядати систему в стаціонарному режимі функціонування. У реальних МПД ця умова на тривалому відрізку часу (доба) не дотримується. Однак на обмежених інтервалах часу $\left(t_{0} \leq 1\right.$ год) можна припустити стаціонарність потоку даних. Графік, що характеризує зміну сумарної інтенсивності потоків даних, які циркулюють у великих СПД протягом доби, подано на рис. 3.

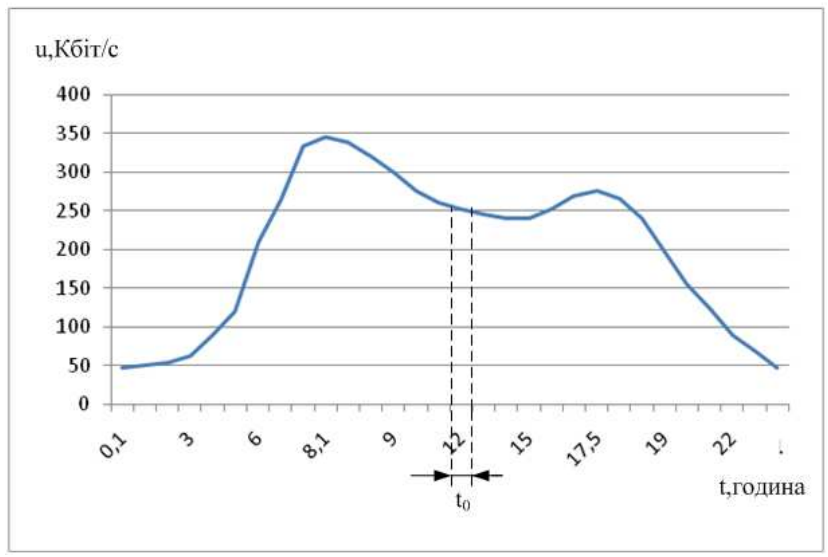

Рис. 3. Характер зміни потоку и протягом доби

Прийнято вважати, що проміжки між надходженням пакетів даних на передачу, породжуваних вузлами мережі, незалежні і однаково розподілені. Формуючи модель МПД, припускають, що потік даних володіє властивостями ординарності і відсутності післядії. Імовірність того, що за час $\boldsymbol{t}_{\boldsymbol{0}}$ буде отримано рівно h пакетів даних при інтенсивності потоку даних i, дорівнює

$P_{h}\left(t_{0}\right)=\frac{\left(u \cdot t_{0}\right)^{h}}{h !} \cdot e^{-u \cdot t_{0}}$ 
Математичне сподівання кількості пакетів даних, що потрапляють на ділянку часу $t_{0}$ дорівнює

$m=u \cdot t_{0}$

Дисперсія пуасонівського розподілу дорівнює його математичному сподіванню

$\delta=u \cdot t_{0}$

Це означає, що кількість пакетів даних, які надходять в одиницю часу, може коливатися в досить широких межах, що відповідає фізичній природі явища (рис. 3).

Потік даних, як і будь-який випадковий процес, можна характеризувати деяким сталим значенням $u_{a, i}$. Ця характеристика враховує не миттєву кількість даних, що передається 3 вузла $y_{a}$ у вузол $y_{i}$, характерну для швидкості передачі, а характер іiі зміни в часі. На практиці значення інтенсивності потоку даних між окремими вузлами мережі можна знайти, виходячи $з$ принципу, притаманного взаємодії двох об'єктів у МПД, за яким інтенсивність обміну даними між вузлами прямо пропорційна добутку потужностей вузлів і пропускних спроможностей каналів ПД між ними i обернено пропорційна відстані між цими вузлами.

Для цього МПД задамо за допомогою неорієнтованого зваженого графа

$S=\left(Y, \varphi_{y}, W, l_{w}, p_{w}\right)$

де $Y$ - безліч вершин $y_{i} \in Y$, графа $S$, що знаходяться в ізоморфізмі 3 вузлами мережі, їх кількість $h_{y}=|Y|$

$\varphi_{y}: Y \rightarrow N_{+}-$вагова функція, яка визначає кожному вузлу $y_{i}$ продуктивність його ЕОМ $\varphi_{y_{i}}($ опер / с); $W$ - безліч ребер графа $S$ (ребро $w_{a_{s} i} \in W$ визначено в графі $S$ між вершинами $y_{a}$ i $y_{i}$, якщо між відповідними вузлами є канал передачі даних);

$l_{w}: W \rightarrow N_{+}-$вагова функція, яка визначає кожному каналу ПД $w_{a_{i} i} \in W$ довжину $l_{w_{a, i}}$;

$p_{w}: W \rightarrow N_{4} \quad-$ вагова функція, яка визначає кожному каналу ПД $w_{a, i} \in W$ пропускну здатність $p_{w_{a . i}}$.

Для безлічі вершин $Y$ будується рівневий граф $B$ (рис. 4) і формується матриця
$H_{b}=\left\|h_{b_{a . j}}\right\|$

де $h_{b_{a j}}$ - кількість рівнів ієрархії МПД, через які необхідно пройти пакету даних при обміні між вершинами $y_{a}$ і $y_{i}$.

Рівневий граф відображає адміністративну підпорядкованість вузлів СПД. Інтенсивність потоків даних, що циркулюють між вузлами по вертикалі, як правило, більше, ніж між вузлами, які знаходяться на одному рівні.

За допомогою алгоритму Данцига визначаються найкоротші шляхи між кожними двома вершинами $y_{a}$ i $y_{i}$ графа $S$ i формується матриця

$L_{m}=\left\|l_{m_{a i}}\right\|$

де $l_{m_{a, i}}-$ довжина найкоротшого шляху між вершинами $y_{a}$ i $y_{i}$.

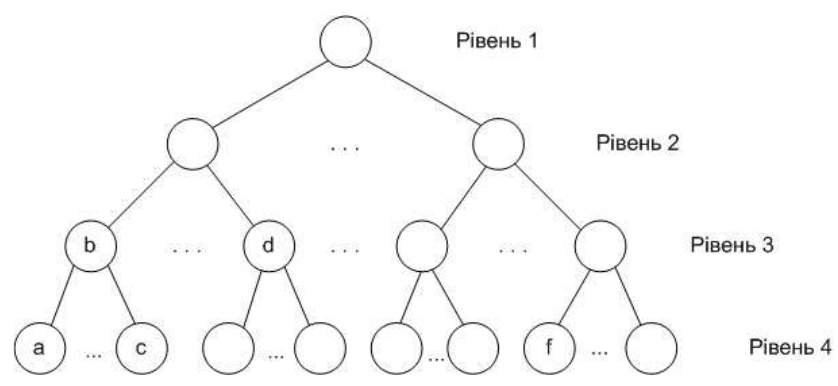

Рис. 4. Рівневий граф $Y$ підпорядкованості вузлів МПД

Пропускна здатність шляху між вершинами $y_{a}$ i $y_{i}$ визначається за допомогою формули

$p_{m_{a, i}}=\min _{w_{j} \in m_{a, i}} p_{w_{j}}$

де $p_{w_{j}}$ - пропускна здатність ребра $w_{j}$ графа $S$, що входить до складу шляху $m_{a_{i} i}$.

Позначимо через $u_{a}$ максимальне значення сумарної інтенсивності потоків даних вершини $Y_{a}$, якими вона обмінюється 3 усіма вершинами множини $Y$, а через $u_{a}$ максимальне значення інтенсивності потоку даних між вершинами $y_{a}$ і $y_{i}$. Тоді максимальне значення сумарної інтенсивності обміну даними вершини $y_{a}$ з усіма іншими вершинами множини $Y$ визначається виразом 
$u_{a}=\frac{l_{p} \cdot \varphi_{y_{a}} \cdot p_{m_{a}} \cdot \sum_{i=1}^{h_{y}} l_{y_{i}} \cdot \sum_{i=1}^{h_{y}} h_{B_{i}}}{h_{y} \cdot h_{0} \cdot \sum_{i=1}^{h_{y}} p_{m_{i}} \cdot l_{y_{a}} \cdot h_{B_{a}}}$,

де $l_{p}-$ довжина пакета даних, що дорівнює від 1024 до 16384 біт;

$p_{m_{a}}$ - середньозважена пропускна здатність шляху між $y_{a}$-ю і іншими вершинами множини $Y$;

$h_{0}$ - число службових операцій процесора ЕОМ, між окремими операціями введення-виведення пакета даних в канал ПД, зазвичай, приймають рівним від $10^{6}$ до $2 \times 10^{6}$ операцій;

$l_{y_{a}}-$ середньозважена відстань між $y_{a}$-ю і іншими вершинами множини $Y$;

$h_{\mathbb{R}_{a}}-$ середньозважений радіус графа $B$ з центром у вершині $y_{a}$.

Середньозважена пропускна здатність шляху між $y_{a}$-ю і іншими вершинами множини $Y$

$p_{m_{a}}=\left(\sum_{i=1}^{h_{y}-1} \frac{p_{m_{a, i}} \cdot l_{m_{a, i}} \cdot h_{E_{a, i}}}{\varphi_{y_{i}}}\right) /\left(\sum_{i=1}^{h_{y}-1} \frac{l_{m_{a, i}} \cdot h_{\bar{b}_{a, i}}}{\varphi_{y_{i}}}\right)$.

Середньозважена відстань між $y_{a}$ - ю і іншими вершинами множини $Y$

$l_{y_{a}}=\left(\sum_{i=1}^{h_{y}-1} \frac{l_{m_{a, i}} \cdot \varphi_{y_{i}} \cdot p_{m_{a, i}}}{h_{B_{a, i}}}\right) /\left(\sum_{i=1}^{h_{y}-1} \frac{\varphi_{y_{i}} \cdot p_{m_{a, i}}}{h_{B_{a, i}}}\right)$.

Середньозважений радіус графа В 3 центром у вершині $y_{a}$

$h_{B_{a}}=\left(\sum_{i=1}^{h_{y}-1} \frac{h_{E_{a, i}}-\varphi_{y_{i}}-p_{m_{a, i}}}{l_{m_{a, i}}}\right) /\left(\sum_{i=1}^{h_{y}-1} \frac{\varphi_{y_{i}} \cdot p_{m_{a, i}}}{l_{m_{a, i}}}\right)$.

Так як $u_{a}$ - це максимальне значення сумарної інтенсивності обміну даними вершини $y_{a}$, то важливу роль відіграє розподіл $\boldsymbol{u}_{a}$ між іншими вершинами множини $Y$. Отримане значення $u_{a}$ розподіляється між взаємодіючими вершинами, зокрема вершиною $y_{i}$, відповідно до виразу

$u_{a_{i} i}=\left(\frac{u_{a} \cdot \varphi_{y_{a}} \cdot p_{m_{i}}}{l_{m_{a, i}} \cdot h_{B_{a, i}}}\right) /\left(\sum_{j=1}^{h_{y}-1} \frac{\varphi_{y_{j}} \cdot p_{m_{a, j}}}{l_{m_{a, j}} \cdot h_{B_{a, j}}}\right)$.

Для кожної пари вершин $y_{a}$ i $y_{i}$, використовуючи вираз (17), розраховуються значення $\boldsymbol{u}_{a_{l} i}$ і $\boldsymbol{u}_{i_{n} a}$ які в загальному випадку можуть бути не рівні один одному.

Відповідно до $\boldsymbol{u}_{\boldsymbol{a}_{a} i}$ i $\boldsymbol{u}_{i_{a} a}$ розраховується середньоарифметичне максимальне значення інтенсивності потоку даних між $y_{a}$-й i $y_{i}$-й вершинами,

$\bar{u}_{a_{i} i}=\frac{u_{a, i}+u_{i, a}}{2}$.

Перерахунок максимальних значень інтенсивностей потоків даних між вузлами мережі здійснюється у разі зміни її структури.

Запропонований спосіб оцінки інформаційних потоків, що циркулюють в МПД, дозволяє визначити максимальні значення інтенсивностей потоків даних між окремими вузлами мережі, з урахуванням ієрархії ïx розташування і відстаней між ними. Отримані значення інтенсивностей потоків даних використовуються при проведенні їх розподілу в процесі адаптивної маршрутизації інформаційних потоків.

Визначення раціональної довжини пакета даних. Пропонований спосіб визначення раціональної довжини пакета даних є складовою частиною методу адаптивної маршрутизації і дозволить максимізувати швидкість передачі повідомлень по каналах ПД в залежності від величини ймовірності спотворення одного біта передачі даних.

Для повідомлень, переданих в МПД, довжина пакета даних $l_{p}$ вибирається постійною. Довжина пакета даних $l_{p}$ не може бути занадто мала, оскільки при фіксованій довжині службової частини (заголовка) пакета знижується частка повідомлення, що передається в одному пакеті. Крім того, збільшуються тимчасові витрати ЕОМ на збирання (розбирання) 
повідомлень і обсяг пам'яті на зберігання описувачів пакетів і їх заголовків.

При великій довжині пакета $l_{p}$ i заданій достовірності передачі даних по каналу ПД підвищується ймовірність передачі пакета даних 3 помилкою i, як наслідок, збільшується частота повторної передачі пакета, що знижує ефективність роботи МПД, а також викликає зростання частки втрати пам'яті ЕОМ через незаповненість інформацією простору, який відводиться під останній пакет повідомлення (під кожен пакет даних у пам'яті ЕОМ відводиться сторінка фіксованої довжини).

Виходячи 3 вищевикладеного i 3 урахуванням практичних рекомендацій раціональна довжина пакета даних $l_{p}$, переданого за маршрутом, може бути визначена за допомогою такого виразу:

$$
l_{p}=\min \left(l_{p_{1}}, l_{p_{2}}\right)
$$

де $l_{p_{2}}$ - раціональна довжина пакета 3 точки зору економії пам'яті та мінімізації системних витрат процесора при обробці повідомлення;

$l_{p_{2}}-$ довжина пакета даних, що забезпечує максимальну швидкість передачі повідомлення по каналу ПД при заданій імовірності спотворення одного біта передачі даних.

Отримане значення $l_{p}$ округляється до найближчого значення, що дорівнює

$$
l_{p}=2^{\mu+1}
$$

де $\boldsymbol{\mu}$-ціле число.

Якщо вважати, що довжина переданих повідомлень в МПД розподілена за експоненціальним законом з математичним очікуванням, рівним $l_{s}$ біт, то 3 точки зору економії пам'яті та 3 урахуванням системних витрат процесора ЕОМ на складаннярозбирання повідомлення, які зростають зі зменшенням довжини пакета, а також враховуючи тенденцію на збільшення довжини переданих повідомлень, раціональна довжина пакета даних визначається виразом

$l_{p_{1}}=k_{1} \cdot\left(l_{b}+\sqrt{k_{2} \cdot l_{b} \cdot l_{s}}\right)$

де $\boldsymbol{k}_{\jmath}$ - коефіцієнт процесорних витрат на складаннярозбирання повідомлення;

$l_{b}-$ довжина заголовка пакета даних (біт);

$k_{2}-$ коефіцієнт блочності.
Значення довжини пакета $l_{p}$, при якому швидкість передачі повідомлення по каналу ПД $V_{p}$ набуває максимального значення, відповідає довжині пакета $l_{p_{z}}$. Швидкість передачі частки повідомлення в одному пакеті даних по каналу ПД визначається виразом

$$
\begin{aligned}
& V_{p}=\left(l_{p}-l_{b}-\frac{h_{b}}{l_{s} / l_{p}+1}\right) /\left(t_{y}+\frac{l_{p}}{V_{w}} \cdot\left(1+P_{0}+P_{0}^{2} \cdots\right)\right)^{\prime} \\
& =\left(l_{p}-l_{b}-\frac{h_{b} \cdot\left(l_{p}-l_{b}\right)}{l_{s}+l_{p}-l_{b}}\right) /\left(t_{y}+\frac{l_{p}}{V_{w}}+\frac{P_{0}}{1-P_{0}} \cdot \frac{l_{p}}{V_{w}}\right)^{\prime}
\end{aligned}
$$

де $h_{b}$ - число вільних біт в останньому пакеті даних;

$t_{y}$ - час комутації пакета даних в ЦКП (c);

$P_{0}-$ ймовірність помилки в пакеті даних;

$V_{w}-$ швидкість передачі даних по каналу ПД (біт / c).

Число вільних біт в останньому пакеті даних визначається з виразу

$h_{b}=l_{p}-\left(\bmod \left(l_{s},\left(l_{p}-l_{b}\right)\right)+l_{b}\right)$,

де $\bmod \left(l_{s},\left(l_{p}-l_{b}\right)\right)-$ залишок від ділення $l_{s}$ на $\left(l_{p}-l_{b}\right)$

Імовірність помилки в пакеті даних можна визначити як

$P_{0}=1-\left(1-P_{\mathrm{C}}\right)^{l_{p}}$

де $P_{\mathrm{C}}-$ імовірність спотворення одного біта передачі даних.

Залежність ймовірності помилки в пакеті даних $P_{o}$ від значень $P_{C}$ наведена на рис. 5, а зміна швидкості передачі повідомлення по каналу ПД в залежності від довжини пакета - на рис. 6. 


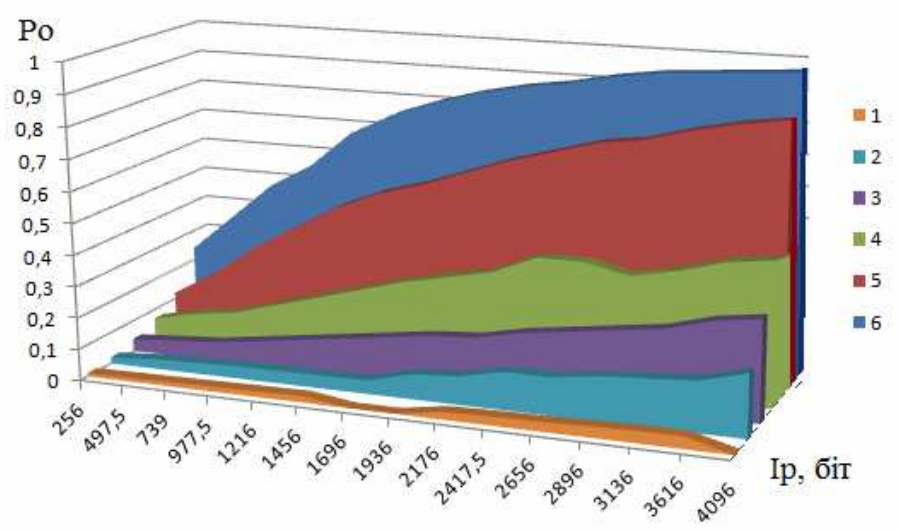

Рис. 5. Зміна ймовірності помилки в пакеті даних в залежності від його довжини: $1-P_{\mathrm{C}}=10^{-5}$; $2-P_{\mathrm{C}}=5 \cdot 10^{-5} ; 3-P_{\mathrm{C}}=10^{-4} ; 4-P_{\mathrm{C}}=2 \cdot 10^{-4} ; 5-P_{\mathrm{C}}=5 \cdot 10^{-4} ; 6-P_{\mathrm{C}}=10^{-3}$

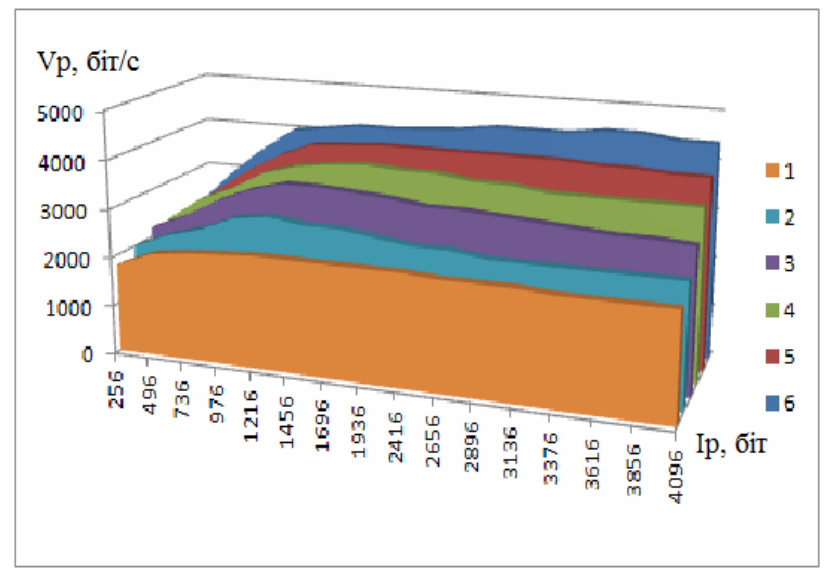

a) $1-P_{\mathrm{C}}=10^{-3} ; 2-P_{C}=5 \cdot 10^{-4} ; 3-P_{\mathrm{C}}=2 \cdot 10^{-4}$; $4-P_{\mathrm{C}}=10^{-4} ; 5-P_{\mathrm{C}}=5 \cdot 10^{-5} ; 6-P_{\mathrm{C}}=10^{-5}$ $V_{\mathrm{w}}=48006 \mathrm{\sigma iT} / \mathrm{c} ; \mathrm{l}_{\mathrm{s}}=1000 \mathrm{Kбіт;} \mathrm{l}_{\mathrm{b}}=96$ біт; $\mathrm{t}_{\mathrm{y}}=0,02 \mathrm{c}$

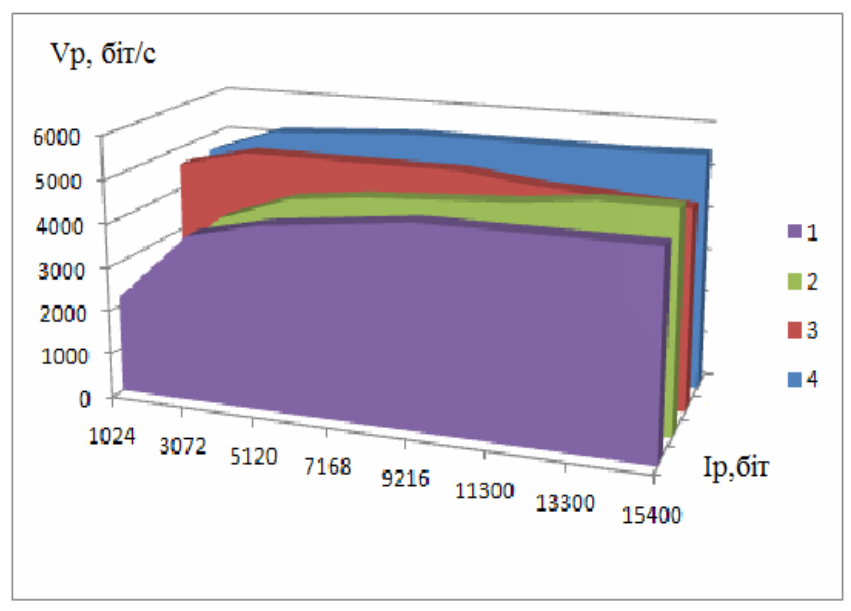

б) $1-P_{c}=10^{-6}, t_{y}=0 c ; 2-P_{C}=10^{-6}, t_{y}=0,02 c$; $3-P_{C}=10^{-5}, t_{y}=0 c ; 4-P_{C}=10^{-5}, t_{y}=0,02 c$; $V_{\mathrm{w}}=56000$ біт $/ \mathrm{c} ; l_{s}=1000$ Кбіт; $l_{b}=192$ біта

Рис. 6. Зміна швидкості передачі повідомлення по каналу Пд в залежності від довжини пакета

Приклад розрахунку раціональної довжини пакета даних наведено в таблиці 2 для вихідних даних (таблиця 1). 
Вихідні дані для розрахунку раціональної довжини пакета даних

\begin{tabular}{|c|c|}
\hline Параметр & Значення \\
\hline Довжина переданого повідомлення, $l_{s}$ & 100000біт \\
\hline Довжина заголовка пакета даних, $l_{b}$ & 192 або 96 біт \\
\hline Коефіцієнт процесорних витрат на складання-розбирання повідомлення, $k_{1}$ & 1,4 \\
\hline Коефіцієнт блочності, $k_{2}$ & 4,8 \\
\hline Час комутації пакета даних в ЦКП, $t_{y}$ & 0 або 0,02 c \\
\hline Швидкість передачі даних по каналу ПД для основного цифрового каналу Пд, $V_{w}$ & 56000 біт/c \\
\hline Швидкість передачі даних по каналу ПД для каналу Пд ТЧ, $V_{w}$ & 4800 біт/с \\
\hline Імовірність спотворення одного біта передачі даних, $P_{C}$ & $10^{-6}, 10^{-5}, 10^{-4}$ \\
\hline Довжина пакета даних, $l_{p}$ & від 1024 до 16384 біт \\
\hline
\end{tabular}

Таблиця 2

Розрахункові значення раціональної довжини пакета даних $l_{p 1}, l_{p 2}, l_{p}$

\begin{tabular}{|c|c|c|c|c|c|}
\hline $\begin{array}{c}V_{w}, \text { біт } / \mathrm{c} \\
l_{b}, \text { біт }\end{array}$ & $\mathrm{P}_{\mathrm{C}}$ & $t_{y,}, \mathrm{c}$ & $l_{p 1}$, біт & $l_{p 2}$, біт & $l_{p,}$ біт \\
\hline & $10^{-5}$ & 0 & 13710 & 4096 & 4096 \\
& $10^{-5}$ & 0,02 & 13710 & 12288 & 16384 \\
$56000 ; 192$ & $10^{-6}$ & 0 & 13710 & 16384 & 16384 \\
& $10^{-6}$ & 0,02 & 13710 & 16384 & 16384 \\
\hline \multirow{2}{*}{$48000 ; 192$} & $10^{-4}$ & 0 & 13710 & 2048 & 2048 \\
& $10^{-4}$ & 0,02 & 13710 & 2048 & 2048 \\
\hline \multirow{2}{*}{$48000 ; 192$} & $10^{-5}$ & 0 & 13710 & 4096 & 4096 \\
& $10^{-5}$ & 0,02 & 13710 & 6144 & 8192 \\
\hline \multirow{2}{*}{$4800 ; 96$} & $10^{-4}$ & 0 & 9638 & 1024 & 1024 \\
& $10^{-4}$ & 0,02 & 9638 & 2048 & 2048 \\
& $10^{-5}$ & 0 & 9638 & 3072 & 4096 \\
& $10^{-5}$ & 0,02 & 9638 & 4096 & 4096 \\
\hline
\end{tabular}

\section{Висновки $з$ дослідження і перспективи, подальший} розвиток у даному напрямку

Таким чином, запропонований спосіб визначення раціональної довжини пакета дозволяє максимізувати швидкість передачі повідомлень по каналах ПД при заданій імовірності спотворення одного біта передачі даних 3 урахуванням обмежень за пам'яттю i мінімізації системних витрат процесора при обробці повідомлення.

Отримане значення довжини пакета використовується при розрахунку середньої затримки пакета даних у МПД, мінімізація якої здійснюється за рахунок розподілу інформаційних потоків, що дозволяє мінімізувати сумарний добуток значень довжин маршрутів і інтенсивностей потоків даних, які розподіляються по них.

\section{Список використаних джерел}

1. Terrence Mak. Adaptive Routing in Network-onChips Using a Dynamic-Programming Network [Text] / Terrence Mak, Peter Y. K. Cheung, Kai-Pui Lam, Wayne Luk // IEEE Transactions on industrial electronics. - 2011. - vol. 58, No. 8. - p. 3701-3716.

2. Patrick Geoffray. Adaptive Routing Strategies for Modern High Performance Networks [Text] / Patrick Geoffray, Torsten Hoefler // 16th IEEE Symposium on 
High Performance Interconnects. - Stanford, California August 26-28. - 2008. - p. 165-174.

3. Королев, А.В. Адаптивная маршрутизация в корпоративных сетях [Текст] / А. В. Королев, Г. А. Кучук, А. А. Пашнев. - Харьков: ХВУ, 2003. $224 \mathrm{c}$.

4. Кучук, Г. А. Використання методів зміни простору рішень для оптимізації управління трафіком мультисервісних мереж [Текст] / Г. А. Кучук, А. А. Коваленко // Системи обробки інформації. - 2016. - Вип. 5 (142). - С. 128-132.

5. Кучук, Г. А. Метод мінімізації середньої затримки пакетів у віртуальних з'єднаннях мережі підтримки хмарного сервісу [Текст] / Г. А. Кучук, А. А. Коваленко // Системи управління, навігації та зв'язку. - Полтава: Полтавський національний технічний університет імені Юрія Кондратюка, 2015. - Вип. 2. - С. 117-120.

6. Трубчанінова, К. А. Дослідження значення величини затримки пакета даних інформаційних потоків в мережах передачі даних [Текст] / К. А. Трубчанінова, Н. В. Свинарьова // Зб. наук. праць Укр. держ. акад. залізнич. трансп. - Харків: УкрДАЗТ, 2012. - Вип. 133. - С. 17-19.

Трубчанинова К. А., Ковтун И. В., Рублев В. А., Соболевская Н. В. Исследование значения величины средней задержки пакета данных информационных потоков в сетях передачи данных. Исследуется значение величины средней задержки пакета данных информационных потоков в сетях передачи данных, для уменьшения которой возможно использование смешанного метода маршрутизации, обеспечивающего адаптацию к изменениям структуры сети передачи данных и минимизацию влияния величины текущего трафика на изменение состояния каналов передачи данных за счет учета максимальных значений интенсивностей потоков данных при проведении их распределения, что позволяет существенно снизить служебные потоки данных.

Ключевые слова: средняя задержка пакета данных, сеть передачи данных, статические методы маршрутизации, динамические методы маршрутизации, адаптивная маршрутизация.

Trubchaninova K. A., Kovtun I. V., Rublev V. A., Sobolievska N. V. Investigation of the value of the volume of the medium delay of the data package of information flows in data-networks. The value of the average delay in the data packet of information streams in data networks is studied, which can be reduced by using a mixed routing method that adapts to the changes in the structure of the data transmission network and minimizes the effect of the amount of current traffic on the change in the state of the data transmission channels by taking into account the maximum values of the intensities data streams during their distribution, which allows to significantly reduce the service data flows. The proposed method for determining the rational length of the packet allows you to maximize the rate of transmission of messages over the channels of the data transmission with a given probability of distortion of one bit of data transmission, taking into account the restrictions on memory and minimizing the system costs of the processor in processing the message.

The resulting value of the packet length is used to calculate the average latency of the data packet in the data transmission network, which is minimized by the distribution of information flows, which minimizes the total product of the lengths of the routes and the intensities of the data streams that are distributed over them.

Keywords: average data packet delay, data transmission network, static routing methods, dynamic routing methods, adaptive routing.

Надійшла 17.10.2017 p.

Трубчанінова Карина Артурівна, канд. техн. наук, доцент кафедри транспортного зв'язку Украӥнського державного університету залізничного транспорту. E-mail: tka2@ukr.net. $\quad$ http://orcid.org/0000-0003-20782647.

Ковтун Ірина Володимирівна, канд. техн. наук, дочент кафедри транспортного зв'язку Українського державного університету залізничного транспорту. E-mail: iryna_kovtun@ukr.net. $\quad$ http://orcid.org/00000002-0740-0539.

Рубльов Вячеслав Олександрович, магістрант ННІППК (Проект TEMPUS IV) Украӥнського державного університету залізничного транспорту. E-mail: timme31101994@gmail.com.

Соболєвська Надія Валеріівна, магістрант ННППК Українського державного університету залізничного трансnорту.E-mail: nadezdas452@gmail.com.

Trubchaninova Karyna, PhD. Sc., associate professor, Department of transport communication of Ukrainian State University of Railway Transport. E-mail: tka2@ukr.net. $\quad$ http://orcid.org/0000-0003-2078-2647. Kovtun Iryna, PhD. Sc., associate professor, Department of transport communication of Ukrainian State University of Railway Transport. E-mail: iryna_kovtun@ukr.net. http://orcid.org/0000-0002-0740-0539.

Rublov Viacheslav, gs of ESIRAT (project TEMPUS IV) of Ukrainian State University of Railway Transport. E-mail: timme31101994@gmail.com..

Sobolievska Nadiia, gs of ESIRAT of Ukrainian State University of Railway Transport. E-mail: nadezdas452@gmail.com. 